\title{
The Contribution of Bronchoalveolar Lavage Performed Before and After Bronchoscopic Biopsies to the Diagnosis of Peripheral Lung Cancer
}

\author{
Dursun TATAR ${ }^{1}$, Ebru GUNES ${ }^{1}$, Ahmet E. ERBAYCU', Nur YUCEL ${ }^{2}$, Huseyin HALILCOLAR ${ }^{1}$ \\ ${ }^{1}$ Dr Suat Seren Chest Diseases and Chest Surgery Training and Research Hospital, Department of Pulmonary Diseases \\ ${ }^{2}$ Dr Suat Seren Chest Diseases and Chest Surgery Training and Research Hospital, Department of Pathology, Izmir, \\ TURKEY
}

\begin{abstract}
The sensitivity of all fiberoptic bronchoscopic techniques in case of a peripheral lung cancer is $69 \%$. In the study, it was aimed to assess the contribution of broncoalveolar lavage (BAL) performed before and after standard biopsy procedures in the diagnosis of peripheral lung cancer.

The patients with peripheral lung lesion in radiology, and normal bronchoscopic findings were included in the study, prospectively. BAL was performed in all patients additionally standard biopsy procedures (forceps biopsy, bronchial brushing, trans bronchial forceps biopsy, trans bronchial needle aspiration). BAL was performed prior (BAL 1) and after (BAL 2) other biopsies. Thirty male with a mean age of 61.9 years were included. In radiology, 26 patients had peripheral-located node or mass and four had an infiltrative pattern of involvement. The cytology / histopathology was adenocarcinoma in 12, non-small cell carcinoma in 9, squamous cell carcinoma in 7 and small cell carcinoma in 2. The cytology of BAL was positive in 6 (20\%). The diagnosis was made by cytology of BAL alone in 1, by standard biopsy procedures in 19, and by trans thoracic needle aspiration in 10. The diagnostic yield, with the combined use of BAL and standard biopsies was $66 \%$. The difference of diagnostic yield between BAL 1 (13.3\%) and BAL $2(20 \%)$ was significant $(p=0.003)$.

The addition of cytology of bronchoalveolar lavage in peripheral lung cancer may increase the diagnostic yield of bronchoscopy and spare some patients from unnecessary invasive procedures. The BAL performed after other biopsy procedures have a significant additive effect on diagnosis.
\end{abstract}

Keywords: Lung cancer, Bronchoalveolar lavage, Bronchoscopy, Biopsy, Cytology, Histopathology

\section{ÖZET}

Bronkoskopik Biyopsi Öncesi ve Sonrasında Uygulanan Bronkoalveoler Lavajın Periferik Akciğer Kanseri Tanısına Katkısı

Periferik akciğer kanserinde fiberoptik bronkoskopi tekniğinin duyarlıı̆ı \%69'dur. Çalışmada, periferik akciğer kanserinde standart biyopsi yöntemlerinden önce ve sonra uygulanan bronkoalveolar lavaj (BAL)'ın teşhise katkısını değerlendirmek amaçlandı. 
Radyolojik olarak periferik akciğer lezyonu ve normal bronkoskopik bulguları olan hastalar prospektif olarak çalışmaya alındı. Tüm hastalara standard biyopsi yöntemleri (forseps biyopsi, bronşiyal firça, trans bronşiyal forseps biyopsi, trans bronşiyal iğne biyopsisi)'ne ek olarak BAL uygulandı. BAL diğer biyopsilerden önce (BAL 1) ve sonra (BAL 2) alındı.

Yaş ortalaması 61.9 yı olan 30 erkek hasta alındı. Radyolojik olarak, 26 hastada periferik yerleşimli nodül veya kitle ve 4 hastada infiltratif görünümde tutulum mevcut idi. Sitoloji / histopatoloji 12 hastada adenokarsinom, 9'unda küçük hücreli dışı karsinom, 7'sinde squamöz hücreli karsinom ve 2'sinde küçük hücreli karsinom ile uyumlu idi. BAL sitolojisi 6 (\%20) hastada pozitif idi. Teşhis, bir hastada BAL sitolojisi, 19'unda standart biyopsi prosedürleri ve 10'unda trans torasik iğne aspirasyonu ile konuldu. Standart biyopsiler ve BAL uygulamasının kombine kullanımı ile tanısal katkı \%66 oldu. Teşhise katkı açısından BAL 1 (\%13.3) ve BAL 2 (\%20) arasındaki fark anlamlı bulundu ( $p=0.003)$.

Periferik akciğer kanserinde BAL sitolojisinin çalışılması bronkoskopinin tanısal katkısını artırmakta ve bazı hastaları gereksiz invaziv prosedürlerden korumaktadır. BAL'ın diğer biyopsi yöntemlerinden sonra uygulanması, tanısal verimini artırmaktadır.

Anahtar Kelimeler: Akciğer kanseri, Bronkoalveoler lavaj, Bronkoskopi, Biyopsi, Sitoloji, Histopatoloji

\section{INTRODUCTION}

Fiberoptic bronchoscopy (FOB) is a regular procedure for investigating patients with suspected primary lung cancer. Endobronchial biopsy has a high diagnostic value in endobronchial lesions visible through the bronchoscope. Transbronchial biopsy and brushing, under fluoroscopic guidance, offer a high diagnostic yield in the investigation of peripheral lung cancer which is not visualized through the bronchoscope. ${ }^{1.4}$ Bronchoalveolar lavage (BAL) was demonstrated to be safe and reliable method for sampling of material from distal airways and alveoli and it is commonly used to assess the interstitial lung diseases..$^{5-7}$ Some studies show high diagnostic yield of BAL in the detection of pulmonary neoplasms with diffuse lesions on the chest radiograph ${ }^{6-10}$ Bronchoalveolar lavage is not only a diagnostic procedure but also a procedure that many tumor markers and other parameters are being searched..$^{11,12}$

In the study, it was aimed to assess the contribution of BAL performed before and after standard biopsy procedures in the diagnosis of peripheral lung cancer.

\section{PATIENTS and METHODS}

\section{Patients}

Patients those had been performed diagnostic bronchoscopy between December 1999 to June 2001 to diagnose peripheral lung lesion (nodule, mass and infiltrates) on chest radiography / thorax computed tomography were included. Peripheral lung lesion was defined as a lesion localized on the peripheral $1 / 3$ of the lung parenchyma at chest radi- ography and thorax CT, without any endobronchial lesion on bronchoscopy. Patients those had been diagnosed benign pulmonary disease, those had failed to have the exact diagnosis, or those had endobronchial lesion in bronchoscopic examination were excluded. All patients $(n=30)$ were diagnosed peripheral lung cancer histologically / histopathologically.

Bronchoalveolar lavage was performed in all patients by FOB. All patients had either 1-3 negative consecutive early morning sputum smears for both acid-fast bacilli identification and cytologic examination or lack of representative specimen (sputum) prior to the exploration.

\section{Procedure of Bronchoscopy and Diagnostic Methods}

Fiberoptic bronchoscopy was performed trans orally with the Olympus BF 1T-30 flexible bronchoscope (Olympus, Tokyo, Japan) by one pulmonologist with the assistance of fellows and dedicating nursing staff. $0.5 \mathrm{mg}$ atropine and $10 \mathrm{mg}$ diazepam were injected subcutaneously, fifteen minutes before examination. The upper airway was anaesthetized with $2-3 \mathrm{ml}$ of $2 \%$ lidocaine solution, which was administered by nebulization, and additional lidocaine was instilled through the bronchoscope as required for control coughing. One or more of forceps biopsy, bronchial brushing, trans bronchial biopsy (TBB), trans bronchial fine needle aspiration biopsy (TBNAB) were performed in all patients. Bronchoalveolar lavage was performed prior (BAL 1) and after (BAL 2) other bronchoscopic diagnostic techniques. TBB was performed for infiltrative 
lesions and TBNAB was performed with the help of $\mathrm{CT}$ for the lesions near the related bronchus.

Bronchoalveolar lavage was performed following general inspection of tracheobronchial tree, by wedging the bronchoscope into a segmental bronchus leading to the abnormal area on the chest radiogram. After wedging the bronchoscope into the related bronchial subsegment, three $20 \mathrm{ml}$ aliquots of normal saline were injected rapidly by handheld syringe and then immediate and gently aspirated until no further fluid was obtained for BAL 1 and BAL $2(60 \mathrm{ml}$ for BAL 1, $60 \mathrm{ml}$ for BAL 2, total $120 \mathrm{ml}$ ). Following BAL 1 brushing was performed in all patients except one with chronic obstructive pulmonary disease. Transbronchial fine needle biopsy and TBB was performed in selected patients by their tomographic features. BAL was repeated similarly for BAL 2 following these sampling methods. The recovered fluid $(60-90 \%$ of $120 \mathrm{ml})$ was transported to the laboratory as soon as possible.

Cytologic examination was carried out to BAL 1 and BAL 2. The fluid was not filtered, only centrifuged. The specimen for cytologic study was centrifugated at $1500 \mathrm{rpm}$ for 10 minutes. The sediment of BAL was smeared into albuminized slides and placed in $95 \%$ alchol for routine hematoxilin-eosin staining. Tissue specimens for histopathologic study were fixed in formalin, embedded in parafin, and stained with hematoxilin-eosin stain.

Trans thoracic fine needle aspiration biopsy (TTNAB) was carried out in patients who had not had exact diagnose by bronchoscopic sampling methods.

\section{Statistics}

Statistical analysis was carried out using SPSS software (package version 13.0, SPSS Inc, Chicago, IL). The analysis between BAL cytology and the localization of lesions (right and left lung) and radiological signs (measurable and un-measurable lesions) were analyzed with Fisher Exact Chi-Square test. The relation between BAL cytology and the diameter of the peripheral lesion were analyzed with Mann Whitney U test. The difference between the two BAL findings in the same patient was assessed with Mc Nemar test. p values less than 0.05 were considered as significant.
The study protocol was approved by the Institutional Review Board Ethics Committee of the Hospital. An informed consent was obtained from each patient.

\section{RESULTS}

Of 35 patients enrolled in the study, 5 patients were excluded because of the diagnosis of another pulmonary disease (pneumoniae in two, pulmonary tuberculosis in two and bronchiolitis obliterans organizing pneumoniae in one). Thirty patients with peripheral primary lung cancer were included in the study. The general characteristics of the patients were shown at Table 1 . Twenty nine patients were smoker or ex-smoker and the mean cigarette package year was $48 \pm 23.8$, while one was non-smoker.

One sputum cytology was malignant (3.3\%). AFB was found negative in sputum, bronchial aspirate and BAL fluid of all patients.

Table 1. The general characteristics of the patients with peripheral lung cancer.

\begin{tabular}{|ll|}
\hline Parameter & $\mathbf{n}(\%)$ \\
\hline Age, years & $61.9 \pm 9.5(37-75)$ \\
Gender, Male/Female & $30 / 0$ \\
Symptoms & \\
Chest Pain & $13(43.3)$ \\
Cough & $8(26.6)$ \\
Weight loss & $7(23.3)$ \\
Hemoptysis & $6(20)$ \\
Other & $1(3.3)$ \\
Asymptomatic & 13.3 \\
Histopathology & \\
Adenocarcinoma & $12(40)$ \\
Non-small cell carcinoma & $9(30)$ \\
Squamous cell carcinoma & $7(23.3)$ \\
Small cell carcinoma & $2(6.6)$ \\
Stage of the disease & \\
IB & $4(13.3)$ \\
IIIA & $3(10)$ \\
IIIB & $14(46.6)$ \\
IV & $9(30)$ \\
& \\
\hline
\end{tabular}


Table 2. The localization of peripheral lung cancer.

\begin{tabular}{lllll|}
\hline Parameter & BAL $(+)$ & BAL $(-)$ & $n(\%)$ & $p$ \\
\hline Localization & & & & \\
Right Lung & 4 & 13 & $17(56.6)$ & 0.670 \\
Apper Lobe Anterior & 2 & 4 & $6(20)$ & \\
Apical & 1 & 6 & $1(23.3)$ & \\
Posterior & - & 1 & $1(3.3)$ & \\
Middle lobe & - & 1 & $2(6.6)$ & \\
Lower lobe lateral & 1 & 1 & $13(43.3)$ \\
Left Lung & 2 & 11 & $5(16.6)$ \\
Upper Lobe Anterior & 1 & 4 & $3(10)$ & \\
Apicoposterior & - & 3 & $1(3.3)$ \\
Lingula & - & 1 & $1(3.3)$ & 0,209 \\
Lower Lobe süperior & - & 2 & $1(3.3)$ \\
Lateral & - & 1 & $42.8 \pm 16.8$ \\
Posterior & 1 & - & \\
\hline Diameter, mm & $60(40-60)$ & $40(20-75)$ & \\
\hline
\end{tabular}

The median diameter of measurable lesions was 40 mm (range: 20-75 mm). Twenty six patients had measurable lesions [seventeen of them had mass lesions $(56.6 \%$, diameter of mass lesions: $40-75$ $\mathrm{mm}), 9$ had pulmonary nodules $(30 \%$, diameter of nodules: $20-30 \mathrm{~mm})$ ]. Four (13.3\%) had un-measurable lesion (parenchymal infiltrates) on chest radiographs. The difference between measurable and un-measurable lesions for BAL positivity was found significant $(\mathrm{p}=0.02)$. There was no relation between the diameter of lesion and the positivity of BAL $1(p=0.252)$ and BAL $2(p=0.209)$ cytology. The localizations of lesions and BAL performed areas were listed in Table 2 .

The relation between localization of lesions and positive BAL cytology was not statistically signifi-

Table 3. The diagnostic methods performed and their contribution to the diagnosis of lung cancer

\begin{tabular}{|llll|}
\hline Diagnostic Methods performed & Number of patients & Number of accurate diagnosis & The rate of diagnosis (\%) \\
\hline Brushing biopsy & 29 & 13 & 44.8 \\
Bronchoalveolar lavage & 30 & 6 & 20 \\
Trans bronchial needle biopsy & 10 & 7 & 70 \\
Trans bronchial forceps biopsy & 4 & 2 & 50 \\
Trans thoracic needle biopsy & 10 & 10 & 100 \\
\hline
\end{tabular}




\begin{tabular}{|lll|}
\hline Table 4. The cytology of BAL 1 and BAL 2 \\
\hline Diagnosis & $\begin{array}{l}\text { Cytology of BAL } \mathbf{1} \\
\mathbf{n}(\%)\end{array}$ & $\begin{array}{l}\text { Cytology of BAL } 2 \\
\mathbf{n}(\%)\end{array}$ \\
\hline $\begin{array}{l}\text { Benign } \\
\text { Malignant * }\end{array}$ & $4(13.3)$ & $18(60)$ \\
Non-diagnostic & $7(23.3)$ & $6(20)$ \\
\hline $\begin{array}{l}\text { Total } \\
\text { 30 }\end{array}$ & $6(20)$ \\
\hline $\begin{array}{l}\text { * Mc Nemar, p= } 0.003 \\
\text { BAL } 1 \text { and BAL 2: Bronchoalveolar lavage performed } \\
\text { prior and after biopsy techniques. }\end{array}$ \\
\hline
\end{tabular}

cant $(\mathrm{p}=0.670)$. The diagnostic procedures performed and the rates of diagnosis were listed in Table 3. Brushing was performed to all patients except one patient with chronic obstructive pulmonary disease. The most valuable diagnostic procedure was TBNAB among all bronchoscopic procedures and the diagnostic value of BAL 1 was $13.3 \%$ and of BAL 2 was 20\% (Mc Nemar, p=0.003) (Table 4).

One patient with pneumonia like infiltration on left lower lobe was diagnosed adenocarcinoma with positive cytology of BAL alone, without any cytological or histopathological diagnostic confirmation for other biopsy techniques (Figure 1).

\section{DISCUSSION}

When BAL is performed both before and after standard bronchoscopic biopsy techniques, the diagnostic contribution to have positive malignant cytology is increasing in patients with peripheral lung cancer. The cytology of BAL, especially when performed after the standard biopsy procedures, may increase the diagnostic yield of bronchoscopy of no significance in peripheral lung cancer.

Lung cancer constitutes $12.8 \%$ of cancer patients and is responsible for $17.8 \%$ of cancer deaths worldwide..$^{10}$ Lung cancer is the most common neoplasm in Turkey too. ${ }^{13}$

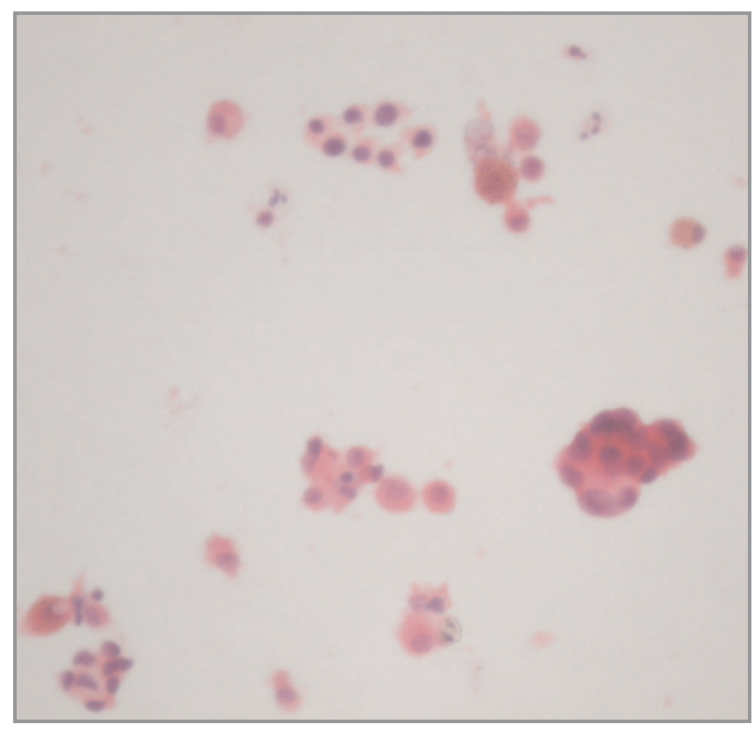

Figure 1. Malignant BAL cytology ( $H E X$ 40. Adenocarcinoma)

Flexible bronchoscopy is an essential part in the diagnosis of a patient with lung cancer with a diagnostic contribution of over $70 \%$. A number of simple techniques are available to obtain the diagnosis of endoscopically visible tumors during the procedures: bronchial biopsy, brushing and fluid aspiration. The pooled sensitivity of these histological and cytological techniques in case of centrally located tumors is $89 \%$. Other sampling procedures, BAL, TBB and/or TBNAB, are available in patients with peripherally located tumors. The pooled sensitivity of FOB techniques in case of a peripheral tumor is $69 \% .^{14}$ The diagnostic yield of FOB techniques in our patients with peripheral lung lesion is determined as $66.6 \%$.

Diagnostic ratio of bronchoscopies is lower for peripheral lesions. The brushing cytology has the highest diagnostic yield, followed by transbronchial biopsies and BAL/bronchial washing. ${ }^{15}$ The overall sensitivity for all modalities in the diagnosis of peripheral lung cancer was $69 \% .{ }^{15}$ Diagnostic value of bronchoscopic procedures in our study was found as $66.6 \%$.

The yields of flexible bronchoscopic evaluation of non-endoscopically visible peripheral masses have wide range (30-60\%). It is related with the experience and the technique of the clinician, the pathological examination as well as the location and the si- 
ze of tumor. The diagnostic value of BAL is higher for the tumors which are greater than $20-30 \mathrm{~mm}$. Pirozynski and Radke et al had shown that correct cell typing was seen in tumors exceeding the diameter of $3 \mathrm{~cm} .{ }^{16,17}$ The diameters of tumors were between 20 and $75 \mathrm{~mm}$ in our patients and there was no relation between the diameter of lesion and BAL cytology.

The sensitivity of sputum cytology is lower in peripherally located masses (49\%) than central lesions $(71 \%) .{ }^{15}$ Only one patient had positive sputum cytology in our study. This may be due to lack of convenient spontaneous sample of sputum.

The diagnostic value of BAL is higher in infiltrative lesions than nodular lesions unrelated to the histological type of lung cancer. Three of 6 patients with malignant BAL cytology had infiltrative (unmeasurable) lesions. These three patients had positive BAL cytology both before and after standard bronchoscopic biopsies. It was thought that infiltrative lesions of lung cancer may cause higher positivity in BAL cytology.

Some studies have described the possibility of tumor seeding during biopsy procedures. ${ }^{18}$ Therefore it was suggested that the postsurgical prognosis of the patients with non small cell lung cancer was significantly better if the preoperative biopsy procedures was unsuccessful. ${ }^{19}$ However peripheral tumors can be determined in advanced stages because of late initiation of symptoms. Most of the patients (76.6\%) in our study had advanced stage disease.

The diagnostic yield of BAL in peripheral lung cancers reported as $14-75.9 \%$, where the bronchoscopic procedures were diagnostic in $16.7 \%$ of patients with non-visible lesions..$^{20}$ This ratio was $20 \%$ in our study and transbronchial needle biopsy was the most useful bronchoscopic sampling method in our patients those without visible lesion. Besides other studies assessing the diagnostic yield of BAL in peripheral lung cancer, we also searched the contribution of BAL performed both before and after standard bronchoscopic biopsy techniques. We concluded that a second BAL performed after other biopsy procedures have significant additive effect on diagnosis.
The addition of cytology of bronchoalveolar lavage in peripheral lung cancer may increase the diagnostic yield of bronchoscopy in peripheral lung cancer and may spare of invasive diagnostic procedures. Infiltrative lesions in radiology may cause higher positivity in cytology of bronchoalveolar lavage.

\section{REFERENCES}

1. Richardson $\mathrm{RH}$, Zavala DC, Mokerjee PK, Bedell GN. The use of fiberoptic bronchoscopy and brush biopsy in the diagnosis of suspected pulmonary malignancy. Am Rev Respir Dis 109: 63-66, 1974.

2. Zavala DC. Diagnostic fiberoptic bronchoscopy: Techniques and results of biopsy in 600 patients. Chest 68: 12-19, 1975.

3. De Gracia J, Bravo C, Miravitlles M, et al. Diagnostic value of bronchoalveolar lavage in peripheral lung cancer. Am Rev Respir Dis 147: 649-652, 1993.

4. Shiner RJ, Rosenman J, Katz I, et al. Bronchoscopic evaluation of peripheral lung tumours. Thorax 43: 887889, 1988.

5. Sacner MA, Wanner A, Landa J. Applications of bronchoscopy. Chest 62 (Suppl 5): 70-78, 1972.

6. Hunningake GW, Gadek JE, Kawanami O, et al. Inflammatory and immune processes in the human lung in health and disease: evaluation by bronchoalveolar lavage. Am J Pathol 97: 149-206, 1979.

7. Reynolds HY. Bronchoalveolar lavage. Am Rev Respir 135: 250-263, 1987.

8. Harpole LH, Kelley MJ, Schreiber G, et al. Assesment of the scope and quality clinical practice gudelines in lung cancer. Chest 123: 7-20, 2003.

9. Russi EW. Lung cancer -A common and deadly disease. Respiration 69: 199-200, 2002.

10. Alberts WM, Bepler G, Hazelton T, et al. Lung cancer. Practice organization. Chest 123: 332-337, 2003.

11. Erbaycu AE, Uçar H, Uslu Ö, et al. Prognostic significance of serum iron, iron-binding capacity, ferritin and bronchoalveolar lavage ferritin levels in primary lung cancer. UHOD 18: 217-225, 2008.

12. Fracchia A, Ubbiali A., El Bitar, et al. A comparative study on ferritin concentration in serum and bilateral bronchoalveolar lavage fluid of patients with peripheral lung cancer versus control subjects. Oncology 56: 181-188, 1999.

13. Lung and Pleural Malignancies Study Group of The Turkish Thoracic Society. Pattern of lung cancer in Turkey, 1994-1998. Respiration 69: 207-210, 2002.

14. van Meerbeeck JP, Tournoy KG. Screening and diagnosis of NSCLC. Ann Oncol 15 (Suppl 4): 65-70, 2004. 
15. Schreiber G, McCrory DC. Performance characteristics of different modalities for diagnosis of suspected lung cancer. Chest 123: 115S-128S, 2003.

16. Pirozynski M. Bronchoalveolar lavage in the diagnosis of peripheral primary lung cancer. Chest 102: $372-$ 374, 1992.

17. Radke JR, Conway WA, Eyler WR, Kvale PA. Diagnostic accuracy in peripheral lung lesions: factors predicting succes with flexible bronchoscopy. Chest 76 : 176-179, 1979.

18. Nordenstrom B, Bjork VO. Dissemination of cancer cells by needle biopsy of lung. J Thorac Cardiovasc Surg 65: 671, 1973.

19. Nakajima J, Sato H, Takamoto S. Does preoperative transbronchial biopsy worsen the postsurgical prognosis of lung cancer: a propensity score-adjusted analysis. Chest 128: 3512-3518, 2005.

20. Roth K, Hardie JA, Andreassen AH, et al. Predictors of diagnostic yield in bronchoscopy: A retrospective cohort study comparing different combinations of sampling techniques. BMC Pulm Med 26: 2, 2008.

\section{Correspondence}

Dr. Dursun TATAR

İmir Göğüs Hastalıkları Hastanesi

Yenişehir, İzmir / TURKEY

Tel: (+90.232) 4333333 / 2253

Fax: (+90.232) 4587262

e-mail: tatar.dursun@gmail.com 